\title{
Work Safety and Health Principles (K3) in the Design of Workshop Center of Artificial Natural Stone in Gianyar, Bali
}

\author{
A. A. Gde Dwika Digjaya Putra ${ }^{1}$, I Nyoman Widya Paramadhyaksa ${ }^{2}$, Ida Bagus Ngurah Bupala ${ }^{3}$ \\ Bachelor Degree of Architecture Study Program \\ Faculty of Engineering-Udayana University \\ Jimbaran \\ dwika.digjaya@gmail.com \\ Architecture Study Program \\ Faculty of Engineering-Udayana University \\ Jimbaran \\ Architecture Study Program \\ Faculty of Engineering-Udayana University \\ Jimbaran
}

\begin{abstract}
The embodiment of Balinese buildings is known to be synonymous with the use of natural stone materials which are exposed in such a way and not given additional dyes/coatings. The material used is usually in the form of bricks and sandstone. The center of the natural stone craftsman is a location of concentration of craftsmen who produce hand-crafted natural stone. The artificial natural stone craftsman center has a workshop used by artisans to produce crafts. In the production process, there is certainly a risk of workplace accidents that can be experienced by craftsmen. At the center must implement occupational safety and health to provide a sense of security and comfort in work. There are many work accidents caused by human factors, workplace accidents must be avoided so that the production of crafts can run smoothly. The risk of workplace accidents that can occur in craftsmen centers in the form of being injured by sharp objects, being hit by a hammer, or falling. The health of craftsmen is also an important factor in the production of artificial natural stones. Healthy craftsmen will be able to work productively and produce good quality craft items. The application of occupational safety and health is expected to be a solution in reducing the risk of workplace accidents that can occur in the production process.
\end{abstract}

Index Terms - centers, craftsmen, accidents, health.

\section{INTRODUCTION}

The embodiment of Balinese buildings is indeed known synonymous with the use of natural stone material which is exposed in such a way and is not given additional coloring / coating. The material used is usually in the form of bricks and sandstone obtained from river banks in Bali. Many of these materials are applied for making ornaments on temples, houses, walls / shearers, merajan, and others. Natural stone which is very much needed for development in Bali has resulted in the use of natural stone being directly proportional to the development in Bali. The building of an artificial natural stone craftsman center in Gian-yar is a centralized location of craftsmen in the Gianyar area who produce similar products and / or work on the same production process, equipped with supporting facilities and infrastructure designed to be able to develop the potential of the area. The same type of product referred to is artificial natural stone, artificial natural stone is natural stone that is processed in such a way that is capable of possessing properties such as natural stone. Natural stone has very promising potential due to the high market demand, on the other hand natural exploitation in natural 
stone producing regions will be a problem going forward. This building will every day produce a variety of artificial natural stone and environmentally friendly materials to meet market needs both in Bali and outside the region. The design of the center of artificial natural stone makers is also expected to be able to absorb labor so that the number of disruptions will be reduced. This center will open up opportunities for cooperation and research between the private sector, regions and academics. This building will be built in Gianyar around the area of Singapadu Village which is still known as a center for natural stone craftsmen.

Natural stone craftsman is one of the civitas that plays an important role in this building. Craftsmen are people whose job is to make handicraft items or people who have skills related to certain handicrafts. These goods are not made by machine, but by hand so that they are often called handicraft goods. Craftsmen are at risk of having a work accident while making crafts. The principle of occupational safety and health (K3) is an important thing that must be applied to this facility so that craftsmen feel safe, comfortable, healthy doing their work so that the quality and quantity of production is optimal.

\section{RESUlt AND ANALISYS}

\section{A. Definition of the Principle of Occupational Safety and Health}

Safety is defined as the absence of an accident, the accident meant is an event that results in an undigested and undesirable loss [1]. According to Law number 35 of 2009, health is a healthy condition, both physically, mentally, spiritually and socially that allows everyone to live productively socially and economically. The principle of safety and occupational health is an effort to prevent the possibility of occupational accidents, illness caused by work, fire, and environmental pollution. The types of hazards in K3 include chemical hazards, physical hazards, and project / work hazards [2]. Chemical hazard is a danger caused by inhalation or human contact with hazardous chemicals. Danger types of physics that is the danger due to temperatures that are too hot or too cold and noise that results in damage to hearing or vision. Dangers of the type of project / work that is the danger of lack of lighting and transportation of goods that can cause injury.

\section{B. Occupational Safety and Health Objectives}

The purpose of occupational safety and health according to Forecast is divided into 4 parts, namely, maintaining and improving the health status of workers in all occupations to the highest level both physically and mentally, preventing the emergence of health problems of the working community due to working environment conditions, provide protection for workers while carrying out their work, and place workers in a work environment based on the skills and physical abilities of the workman. Maintaining and increasing the degree of workers is manifested in the design by providing comfort in the space and supporting space needed for work, such as toilets, break rooms, and pantry. Preventing the emergence of health problems in the field can be applied by using personal protective equipment (PPE), in the design of preventing the emergence of health problems can be realized by preventing physical disturbances from space by taking into account lighting and space maintenance. Workers can be protected by making a safe circulation of space and designing efficient circulation.

\section{The Implementation of Occupational Safety and Health Principles in the Workshop Area Circulation}

Circulation is a movement made by users or users of buildings in the site and buildings (Laksito, 2014). The perpetrators are humans, vehicles and goods. The circulation aspect is very important for a building because good circulation can facilitate the movement process that is inside. Good circulation is also inseparable from the standard size used in the elements inside. The standard size used is based on SNI and neufert measurements. The standard size is used to comfort the existing civitas mobility. At the center of natural stone craftsmen, the workshop area is placed at the back of the site so as not to disturb visitors who enter the facility. The workshop area has one entrance intended for goods and raw material transportation vehicles, craftsman vehicles, employee vehicles. In addition to the entrance to the workshop area, if the citizens want to enter the workshop from the main building, they can take the road next to the ramp of the main building. The road is also intended for goods or craft transportation routes to the gallery. More details can be seen in the following figure 1.

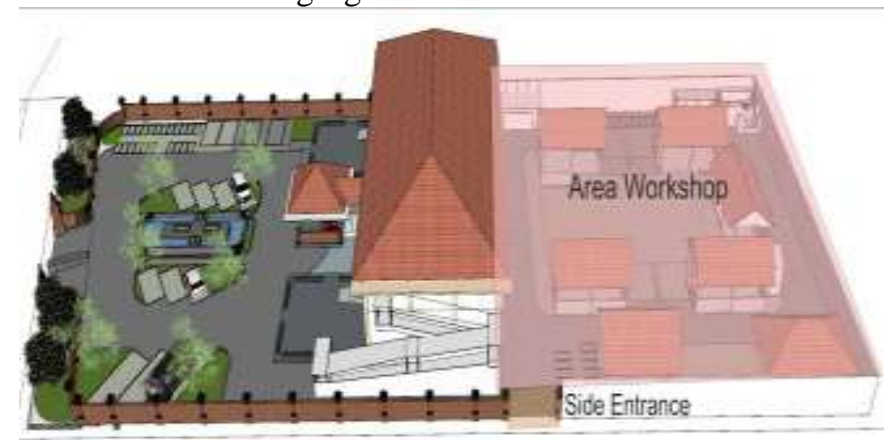

Fig. 1. Workshop area at the Craftsman Center

The application of safety and health in the circulation of the workshop area can be seen from the separation between the areas that cause heat with the workshop space, arrangement of raw materials close to the work space to facilitate production, and the existence of space for rest, prayer, food and latrines. The workshop room is located centrally to the place of drying to facilitate the circulation of handicrafts made to be easy to place. The combustion chamber has a risk to disrupt the health of the community in the workshop area and therefore the combustion 
chamber is placed in a place far from the dense activities of the craftsmen so as not to cause danger. Elements in the workshop area such as the size of the road and parking are guided by established standards so that comfort in circulating can be achieved. More details can be seen in Figure 2 below.

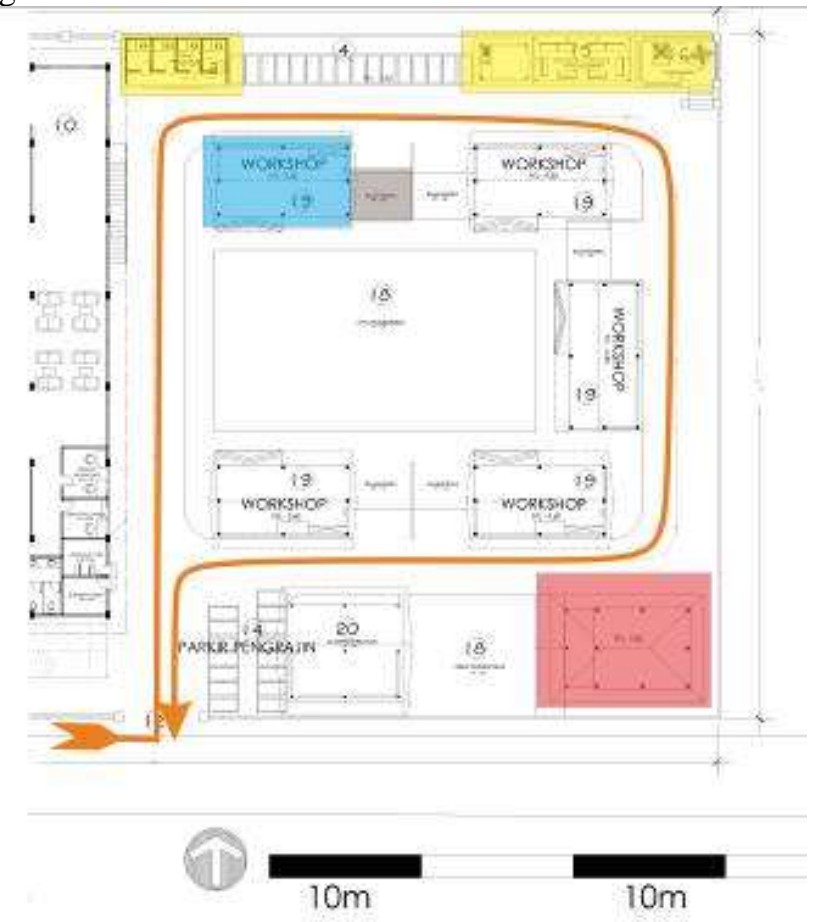

Fig. 2. Application of K3 in the Workshop Area Circulation

Human circulation is made so that the community is easy to move from one room to another, such as from the workshop room to the toilet room and break room. A craftsman who has just parked his vehicle can go straight to the workshop area through the road and can circulate at the edge of the drying area. In the workshop area that requires health support rooms such as toilets, pantry, rest room, and padmasana are focused in the upper area so that the circulation for the commander who wants to go to the support room becomes grouped. These supporting spaces are useful for maintaining the health of craftsmen both physically and mentally. More details can be seen in the following figure 3 .

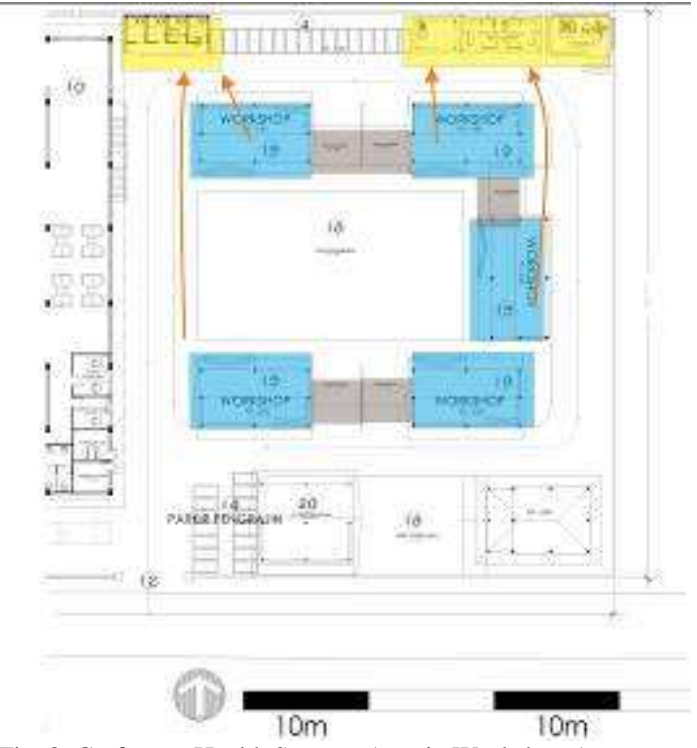

Fig. 3. Craftsman Health Support Area in Workshop Area

Circulation of vehicles in the workshop area is made with attention to occupational safety and health, such as the craftsman parking area which is placed close to the entrance and does not interfere with the activity of cars that will enter the workshop area. The width of the road in the workshop area is $3.80 \mathrm{~m}$ which is sufficient for the vehicle to enter. in certain functions, circulation within the site is actually dominated by the movement of objects and goods, for example planning factory buildings, craftsmen and warehousing (Laksito, 2014). Circulation of goods is made as efficient as possible in order to reach craftsmen quickly with workers more comfortable working because of the transportation of goods faster. The goods circulating in the workshop area are the raw material for making handicrafts, finished crafts, bricks, and craft waste. The application of the $\mathrm{K} 3$ principle to the circulation of goods is realized by making the goods easy to transport both to the workshop room and outside the center. Goods that leave the workshop area are usually taken from the warehouse and drying area. More details can be seen in the following figure 4 . 


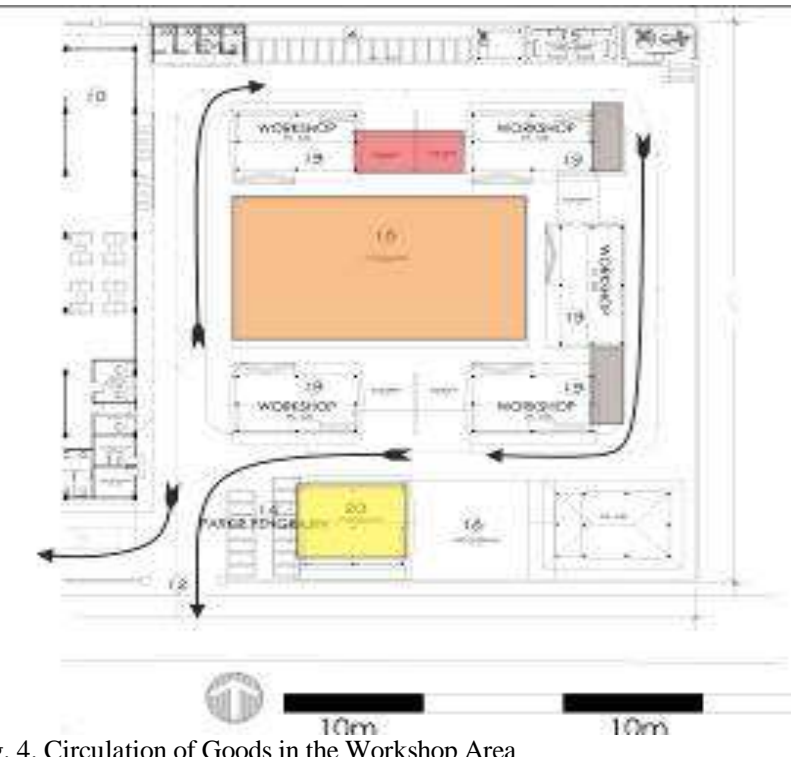

Fig. 4. Circulation of Goods in the Workshop Area

\section{Application of the Principle of Occupational Safety and Health (K3) in the Workshop Room}

Comfort in a space depends on human culture and customs, especially climate and humidity, air pollution, natural and artificial radiation, building material shapes and structures, and the color and lighting of a room [3]. The workshop room is a space for craftsmen to produce handicrafts that are needed comfort to maintain the work health of the craftsmen. This space is very important for the running of other activities at the center of the craftsmen. Activities in the workshop room are at risk of accidents due to using sharp tools. Types of accident hazards that can occur are, inhalation of sculpted dust, hot temperatures, lack of lighting and transportation as well as the use of incomplete equipment that can cause injury to craftsmen.

The picture shows that there is a ramp element in the workshop room. The ramp element has a function to make it easier for craftsmen to move crafts or raw materials. By making it easier to transport goods, craftsmen can produce handicrafts more easily and maintain their health. The workshop room applies a $120 \mathrm{~cm}$ wall so that lighting and air can be maximized in space and craftsmen are free in the room. Element under the room using finishing acian to provide a non-slippery floor. More details can be noted in the following figure 5 .

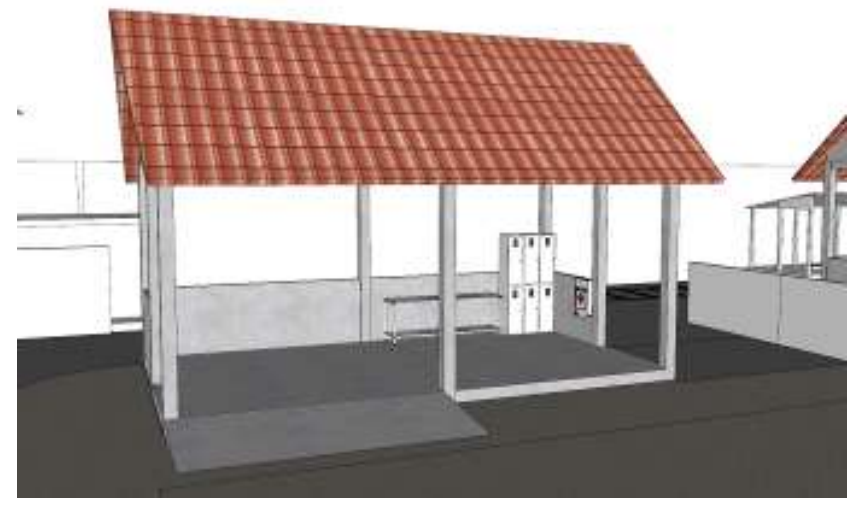

Fig. 5. 3D Perspective Workshop Room

Comfort in the workshop is given to maintain the health of the craftsmen. This comfort can be achieved by applying the required standard amount of wiggle room. Anthropometry studies the measurement of human body dimensions which are widely used for ergonomic considerations in design designs [4]. The size of the body in the activity is very influential in the design process, especially in architectural design, for example in determining the size of the stairs, building height, door size, and the layout of facilities and utilities. The height of the workshop space is not out of human scale so the craftsmen in it will feel comfortable in accordance with the application of anthropometry in building designs. $320 \mathrm{~cm}$ high workshop which is ideal for craftsmen to work. Civitas who do heavy work require space of $3 \mathrm{~m} 2 /$ person (Neufert, 2002). This measure has been used as a standard measure in designing this workshop that is adjusted to the craftsmen and the items in it. More details can be seen in Figure 6 below.

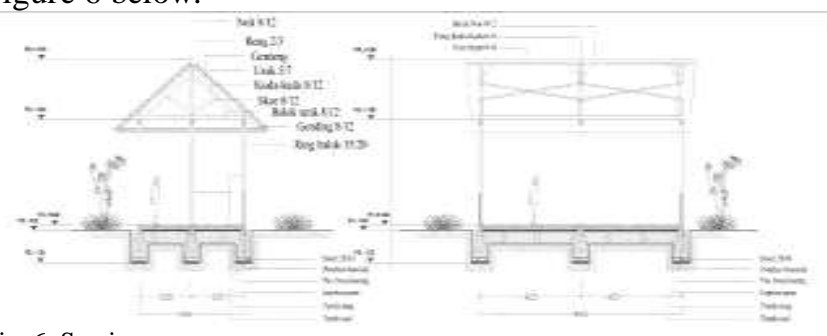

Fig. 6. Secsion

\section{CONCLUSION}

The center of artificial natural stone craftsmen in Gianyar is a location for craftsman concentrations in the Gia-nyar area that produce similar products and or work on the same production process, equipped with supporting facilities and infrastructure designed to be able to develop the potential of the area. Natural stone has very promising potential due to the high market demand, on the other hand natural exploitation in natural stone producing regions will be a problem going forward. At the center must apply occupational safety and health (K3) to provide a sense of security and comfort in work. Many work accidents occur in every craft production caused by human factors, work accidents must be avoided so that the production of an item can run smoothly. The purpose of K3 itself is to maintain the safety of craftsmen and maintain work efficiency so that they can produce quality products. The principle of OSH is applied to the workshop area as seen from the placement of the building and its circulation, both human, vehicle and material circulation. The workshop space used by the craftsmen also applies the K3 principle. The workshop room is designed by taking into account the comfort of the craftsmen's movement space, the selection of materials that are safe to work so as to create a safe space that does not interfere with the health of 
Journal of A Sustainable Global South, p-ISSN: 2579-6062

the craftsman.

\section{REFERENCES}

[1] Alli, Benjamin O., "Fundamentals Principles of Occupational Health and Safety", Geneva: International Labour Organization, 2008.

[2] Irzal, "Dasar-dasar Kesehatan dan Keselamatan Kerja", Jakarta: Kencana, 2006.

[3] Frick, Heinz \& Tri Hesti Mulyani, "Arsitektur Ekologis seri 2", Semarang: Kansius Yogyakarta, 2006.

[4] Panero, Julius dan Zelnik, Matrin, "Dimensi Manusia dan Ruang Interior: Buku Panduan untuk Standar Pedoman Perancangan”, United State: Whitney Library of Design, 1979. 